\title{
Job Crafting and Employees' Performance in MTN Nigeria, Plc
}

\author{
GENTY, KabiruIshola ${ }^{1}$,ABIORO, Matthew Adekunle ${ }^{2}$, SHOFOWORA, Oluwatobiloba ${ }^{3}$ \\ Lagos State University, Ojo \\ Department of Industrial Relations and Human Resource Management ${ }^{1,3}$ \\ Lagos State University, Ojo \\ Department of Business Administration ${ }^{2}$ \\ Federal University of Agriculture, Abeokuta
}

Emails: ishola.genty@lasu.edu.ng ${ }^{1}$, abioroma@ funaab.edu.ng $^{3}$

DOI: 10.36108/ljerhrm/0202.02.0131

\begin{abstract}
This study examines the relationship between job crafting (task crafting and relational crafting) and employees' performance (employees' task performance and organizational citizen behaviour) amongst staff of MTN Nigeria Plc. This research makes use of a survey design and analysis was based on primary data generated through a structured questionnaire. Two research hypotheses were formulated and tested at 0.05 level of significance. The findings revealed that there was a statistically significant influence of task crafting on employees' task performance in MTN Nigeria, Plc $\left(R^{2}=.088, F=17.844, p<0.050\right)$. Similarly, there is a significant positive relationship between relational crafting and organizational citizen behaviour $\left(r_{p}=0.331, n=187\right.$, $p<0.050$ ). From the study, it was concluded that workers require a high degree of autonomy and independence on their jobs to perform more efficiently and effectively in order to improve their performance. It was recommended amongst others that organization should provide a flexible job design and structure as well as interpersonal relationship for its employees' so as to enable them to better perform on the task and create organizational citizen behavior among the employees.
\end{abstract}

Keywords: Employees' performance, Job crafting, Relational crafting, Organizational citizen behaviour

\section{Introduction}

The challenging economic situation has put increased pressure on organizations in recent years. Most organizations are relying on their internal resources to achieve higher levels of performance and productivity rather than rely on favorable external factors (Buchner, 2007). The practice of Human Resource has shifted away from the employer-focused notion to the employee-oriented practice, in order to increase the employees' level of intrinsic motivation. Due to this change, the proactive behavior of the employee which contributes to the level of performance could be beneficial to the employee as well as the organization.

One of the most critical factors of an organization with respect to its output and profitability are its employees. That is, how competitive an organization will be is largely depends on the total sum of its work-related activities especially the way job are design and structure among its employees (Cascio \&Aguinis, 2014). Employees will commit themselves to their tasks when they perform their preferred tasks, and the tasks are well matched to the needs of the employees. Therefore, to find maximum performance, an organization must make an effort towards finding 
the most suitable employees for a specific task. However, it is not easy to match the optimum employee with their ideal tasks through employment and human resource management .Thus, job crafting becomes imperative.

Although almost all employers have something in common towards goal accomplishment but they look for ways to promote a healthy and engaged workforce. This is because a healthy and engaged workforce tends to perform better, have higher levels of productivity and they are generally happier in their roles as well as get committed to the organisation. Employees with negative feelings of well-being and low engagement tend to bring down both company culture and profitability, counterproductive work behavior, and lack of organizational citizenship behaviour (Peral \& Geldenhuys, 2020). However, most employers are faced with the challenge of getting the ideal person to perform the required tasks within the organization. Often times, certain individuals are saddled with responsibilities which they consider too difficult to undertake thereby leading to poor and inefficient performance. Such employees are considered misfits for such jobs due to the skills gap.

Therefore, there is need to either replace the individual or redesign the job characteristics. Replacing the individual might be quite unachievable because of social, demographic, legal as well as economic constraints. Generally speaking, there is a need to create an environment for the employee to better adjust to his roles and duties without deviating from the organization's set goals and objectives through task and relational crafting.

Hence, the question of whether job crafting improves or worsen employees performance is still worthy of further research. It is against this backdrop that this study attempts to access the influence of job crafting vis-à-vis employees' performance in the Nigerian telecommunication industry.

However, the specific objectives of the study were to evaluate the influence of task crafting on employees' task performance and to determine the relationship between relational crafting and organizational citizen behaviour drawing insights from workers of MTN Nigeria Plc.

\section{Literature Review}

This section examines the works of authors and scholars that are related to the study. The review of these works is therefore presented under the following sub-headings: Conceptual review, theoretical review and empirical review of previous studies.

\section{Conceptual Review}

\section{Job Crafting}

Wrzesniewski and Dutton (2001) refer to job crafting as "the actions, employees take to shape, mold, and redefine their jobs" (p.). It is often believed that employees can be motivated through the design of their job but since employees working in contemporary organizations likely has at least some latitude to modify their jobs (Oldham \& Hackman, 2010). Therefore, there is increasing interest in the way employees influence or shape their own jobs. The process of shaping jobs so that tasks and social interactions better suit an individual's needs, abilities, and preferences has been called job crafting (Wrzesniewski\& Dutton, 2001). 
Job crafting is conceptualized as the changes employees make to balance their job demands and job resources with their personal abilities and needs (Tims, Bakker \&Derk, 2012). Job crafting is a proactive behavior, in that individuals take an active role in their approach towards their work, initiate future-oriented actions, and create favorable conditions ( $\mathrm{Li}$, Jin\& Chen, 2018; Bindl\& Parker, 2011; Crant, 2000: Grant \& Ashford, 2008). Employees can change previously constructed job roles by changing their tasks and social interaction on the job so as to change work meaning and work identity (Bohnlein\& Baum, 2020; Wrzesniewski\& Dutton, 2001).

Wrzesniewski and Dutton (2001) identified three key job crafting activities namely; task crafting, relational crafting, and cognitive crafting.

Task crafting: Task crafting is concerned with how employees actively mould their job tasks, changing the scope of the tasks, and by changing the means being used in the accomplishment of tasks. According to Peral and Baum (2020) task crafting is the process of making work more meaningful by employees through the changing of the amount or type of work that employees do.

Relational crafting: Relational crafting has to do with the change in the quality and quantity of social interaction at work, interpersonal relationship and teamwork among others. This is when an employee change work situation or structure as a result of deciding how he or she interacts with colleagues (Peral \& Geldenhuys, 2020).

Cognitive crafting: Cognitive crafting centers on reframing the employee's perception of their job and changing the employee's cognitive representation of the job. That is, this occurs as a result of workers changing personal perspective about their work.

In line with Wrzesniewski and Dutton (2001), Tims, Bakker and Derks (2012), emphasized that job holders initiate a bottom-up redesign. This implies that the crafting behavior of changing job demands can be linked to task crafting while changing job resources can be linked to relational crafting (Demerouti, 2014). Although these two approaches seem similar, but both conceptualizations view job crafting from varying perspectives. Tims et al, (2012) built their conceptualization on the job demand-resources model (JD-R) and propose that individuals strive for a more meaningful, suitable, engaging, and satisfying job, but also for the protection of their own health, that is, actively coping with job stress.

To Wrzesniewski and Dutton (2001), job crafting is conceptualized as individuals aligning their work with their individual needs and values to find personal meaning that is the main target of job crafting is one self. It is worthy to mention at this juncture that the term job crafting emerged from job design theory. The traditional form of job design is the prerogative of the manager who designs jobs for employees in a top-down manner. However, the contemporary worker initiates proactive changes to their jobs rather than remain as passive recipients of job functions.

\section{Employee Performance}

Employee performance is highly valuable because it contributes to the organization's technical core (Borman \&Motowidlo, 1997). Employees' performances have usually been measured in terms of job performance which is multi-dimensional (Austin \&Vilanova, 1992). Several 
behaviours of the employees have an impact on their performance. These behaviours include organizational citizenship or altruism as well as counterproductive work behavior (CWB) (Dalal, 2005: Staufenbiel\& Hartz, 2000). These behaviors are very important as they serve as catalysts for tasks activities and processes.

Rotundo and Sackett (2002) have suggested that there are three broad performance domains; task performance, organizational citizenship behavior or altruism and counterproductive work behavior (CWB).

Task performance: These are all behaviors and outcomes that directly serve the purpose of the organization.

Organisational citizen behavior or altruism: This is a discretionary behavior on the part of an employee that is believed to directly promote the effective functioning of an organization without necessarily directly influencing an employees' productivity (Genty, Fapohunda, Jayeoba\& Azeez, 2017; Staufenbiel\& Hartz, 2000; MacKenzie, Podsakoff \& Fetter, 1991). Altruism goes beyond the content of the formal job description which improves organizational effectiveness.

Counterproductive work behavior $(C W B)$ : This is an intentional employee's behavior that is harmful to the legitimate interest of an organization (Gruys\& Sackett, 2003).

In essence, the general contribution of an employee to the organization can be assessed using the above three instruments.

\section{Theoretical Review}

Wrzesniewski (2016) claimed that "the three types of job crafting are not mutually exclusive, and job crafters may exercise any combination of the three". Wrzesniewski and Dutton (2001) illustrated the phenomenon of job crafting and built their theoretical framework mainly on the basis of qualitative studies. In alignment with the position of Wrzesniewski and Dutton (2001), Tims et al (2012) emphasized that job holders initiate a bottom-up redesign.

Demerouti (2014) therefore stated that the crafting behaviour of changing job demands can be linked to task crafting while the changing of job resources can be linked to relational crafting. For clarity seek, this study adopted job demands resource theory developed by Bakker and Demerouti (2007). This is because job resources refer to physical, psychological, social or organizational aspects of the job that are either/or stimulate personal growth, learning and development. This in turn will transcend to employees performance.

Due to the diverse end products of modern labour, it is obvious that working conditions can differ from one organization to the other. In spite of these organizational differences, Jobdemands Resources theory according to Bakker and Demerouti proposes that all job resources characteristics can be classified into two main categories, i.e., job demands and job resources which have been described to have unique properties and predictive value.

Job -demands are the aspects of work that require physical and cognitive efforts of the job holder. It involves the categories of jobs that cost energy like workload, complex tasks and conflicts. However, job demands can be sub-divided into challenge demands (which entail 
workload and complexity) and hindrance demands (which involve conflict). While challenge demands help workers to perform well, hindrance demands on the other hand undermine performance.

Job resources are the aspects of work that help employees to deal with job demands and achieve their goals. Job resources include such elements as social support, performance feedback, etc. Both job demands and job resources have unique and independent effects on employee wellbeing, which in turn reflects on job performance. Employees' exposure to daily workload may transform into chronic overload over a long time period, which often leads to physical health problems while job resources initiates a motivational process.

Thus, job resources influences motivation when job demands are high. Job holders often rely on autonomy, skill variety, performance feedback and task identity when the job demands become challenging. Therefore, job resources are particularly useful and motivating when needed. Job characteristics are distinguished in demands and resources (Bakker \& Demerouti, 2007). In order word job demands refers to "physical, psychological, social, or organizational aspects of the job that require sustained physical and/or psychological (Cognitive and emotional) effort or skills and are therefore associated with certain physiological and/or psychological costs."

\section{Review of Previous Empirical Studies}

The relationship between job crafting and job performance has been examined in several studies ranging from qualitative studies to quantitative studies. From these studies, it appears that job crafting mainly has a positive relationship with job performance based on the arguments that crafting one's job demands and job resources may lead to work engagement and job performance. It is expected that work engagement may mediate the relationship between job crafting and job performance (Demerouti et al, 2014). In previous numerous empirical studies, some researchers have been able to identify that employee job crafting behavior differs due to personal factors and environmental factors (Bohnlein\& Baum, 2020; Peral \& Geldenhuys, 2020; Li, Jin\& Chen, 2018; Peng, 2018; Ogbuanya\&Chukwuedo, 2017; Niessen, Weseler\&Kostova, 2016; Vogt, Hakanen, Brauchi, Jenny \& Bauer, 2015; Wrzesniewski\& Dutton, 2001).

Wrzesniewski and Dutton (2001) argue that discretion, decision latitude and job autonomy in work has strong predictive effect on job crafting, but tight job monitoring may hinder job crafting. In essence, they concluded that a supportive organizational climate helps employees to generate positive working attitude and behavior. Therefore, Wrzesniewski and Dutton established that reasonable degree of job autonomy and independence is required to enhance job crafting behaviour.

Niessen, Weseler and Kostova (2016) focus on antecedents of job crafting, the development and validation of a job crafting scale. In the first study $(\mathrm{N}=466)$, an exploratory factor analysis with one half of the sample $(n=233)$ and a confirmatory factor analysis with the other half $(n=233)$ supported a three-dimensional structure of job crafting (task crafting, relational crafting and cognitive crafting), and convergent as well as discriminant validity of job crafting in relation to personal initiative and organizational citizenship behavior. In Study 2 ( $\mathrm{N}=118)$, Niessen et al (2016) cross-validated the measure and demonstrated that job crafting was related to, yet distinct from taking charge. It was discovered that an increase in job crafting at Time 2 was predicted by need for positive self-image (Time 1), as well as by work experience (Time 1). 
The most recent work in Nigeria on job crafting and performance was the study conducted by Ogbuanya and Chukwuedo (2017). The study investigated the multiple mediating roles of work engagement and work commitment in the job crafting-job satisfaction relationship. Using bootstrap method for 247 electrical/electronic technology education lecturers' participants in Nigeria universities, the study found that job crafting has positive significant prediction of work engagement, work commitment and job satisfaction. Similarly, the path analysis results revealed that work engagement and work commitment has full mediation on the job crafting-satisfaction relationship.

Li, Jin and Chen (2018) examined the relationship between proactive personality and creative performance using job crafting as a mediator. The study adopted longitudinal research design with 346 employees and their supervisors in 27 high technology firms in China. In the study it was found that proactive personality was positively related to creative performance while job crafting mediated this relationship. However, an indirect effect of proactive personality on creative performance through job crafting was significant when high-involvement work system was low but not high.

In a study conducted by Bohnlein and Baum (2020) using meta-analytic technique, 20,547 participants were used to measure the effects of job crafting on individual in-role and extra-role performance of worker. The study found that promotion-oriented job crafting associated with increase well-being and both in-role and extra-role performance. Meanwhile prevention-oriented crafting yielded partially non-significant relationships with both performance outcomes.

Peral and Geldenhuys (2020) examined the indirect relationship between personality and performance through job crafting. Using Structural Equation Modelling (SEM) to investigate 580 sample of South African working individuals found that the 'Big five' personality traits indirectly influenced job performance such as in-role behavior, organizational citizen behabiour through job crafting as a mediator.

\section{Methodology}

This research makes use of a survey design and analysis based on primary data generated through a structured questionnaire administered to the respondents. The survey research method was most appropriate because the researcher has no control of the variables as well as the outcome. The targeted population of this study is three hundred and fifty (350) employees which consist of both temporary and permanent staff of MTN Nigeria PLC, Lagos. Taro Yamane's statistical formula was applied to get a sample size of 187 participants use in the study.

The sampling technique used in this study is the simple random sampling as there is no discrimination between senior and junior staff of the organization. Simple random sampling refers to a variety of selection techniques in which sample members are selected by chance, but with a known probability of selection. Therefore, all employees of the organization have equal chance of participating in the process. In order to get better and relevant data, structured questionnaire was constructed to provide answers to the research questions raised in the study. The questionnaire was divided into two sections which consist of section A which is the Biodata of the question and section B which is the operational data. The questionnaire made up of twenty (20) items from which the respondent is expected to choose the option he/she consider suitable for him by ticking appropriately using 5-likert scale. 
The questionnaire was validated through a critical review by expert in psychometric while a pilot study was conducted on 20 employees of Global telecommunication as respondents. This is to know their understanding and interpretation of the questions in order to ensure that such questions bear some meaning. The comments and/or queries raised by those respondents were used to fine-tune the questionnaires. The reported Cronbach Alpha is more than 0.7 benchmark threshold.

\section{Data Analysis and Interpretation}

This part presents the descriptive statistics of data used for the study. The data table used here is to present the data and analyses it by using frequencies and percentages. Pearson product moment correlation and regression analysis was adopted to examine the degree of the relationship that exist between two variables and to explain the data.

\section{Demographic Characteristics of Respondents}

This section provides demographic information of the respondents of the study. The characteristics include; age, gender, level of educational qualification, years of working experience and marital status.

Table 4.1: Respondents Demographic Characteristics

\begin{tabular}{ccc}
\hline Variables & Frequency & Percentage \\
\hline Age Group & 9 & 4.8 \\
Below 20 years & 81 & 43.3 \\
20 - 30 years & 77 & 41.2 \\
31 - 40 years & 20 & 10.7 \\
41 years \& above & & \\
Gender & 102 & 54.5 \\
Male & 85 & 45.5 \\
Female & & \\
Level of Education & 2 & 1.1 \\
Primary School & 20 & 10.7 \\
Secondary School Certificate & 49 & 26.2 \\
Vocational Education & 114 & 61.0 \\
Bachelor's Degree/HND & 2 & 1.1 \\
Others & & \\
Working Experience & 79 & 42.2 \\
Below 5 years & 79 & 42.2 \\
5 - 10 years & 20 & 10.7 \\
11 - 20 years & 9 & 4.8 \\
20 years \& above & & \\
Marital Status & 66 & 3.2 \\
Single & 102 & 54.5 \\
Married & 13 & 7.0 \\
Divorced & 6 & \\
Widow/widower & & \\
\hline 2020. & & \\
\hline
\end{tabular}

Source: Author, 2020. 
Employees were asked to indicate their gender. Table 4.1 revealed that $54.5 \%$ of the respondents were male while $45.5 \%$ of the respondents were female. The findings indicated that there is a gradual paradigm shift from the concentration of females in the telecommunications industry to create a balance between the two genders and this made the number of male respondents to exceed their female counterparts by $9 \%$.

Table 4.1 shows that $9(4.8 \%)$ of the respondents falls within the age bracket of less than 20years, while $81(43.3 \%)$ of the respondents falls within the age bracket of 20-30years, 77 $(41.2 \%)$ of the respondents falls within the 31-40years and $20(10.7 \%)$ of the respondents falls within the age bracket of 41years and above. This analysis revealed that most of the respondents were within the age bracket of 20-30years. MTN Nigeria PLC adopts the recruitment of young graduates due to the flexibility of the job tasks. Majority of the respondents who are less than 30years of age are more likely to perform actively than the older counterparts.

Table 4.1 also shows that $2(1.1 \%)$ of the respondents falls within the Primary Education category, $20(10.7 \%)$ of the respondents had Secondary Education, 49 (26.2\%) had vocational education, $114(61 \%)$ were BSc/HND holders and $2(1.1 \%)$ had either OND or PhD. Majority of the respondents are BSc/HND holders as this is the benchmark for most job positions in the organization. Similarly, Table 4.1 shows that 79 (42.2\%) of the respondents had less than 5 years of working experience, 79 (42.2\%) had 5-10years working experience, $20(10.7 \%)$ had 1120years working experience and $9(4.8 \%)$ of the respondents had 21years and above working experience. This states that majority of our respondents have been working with MTN Nigeria, Lagos for less than ten years. Due to the high concentration of the respondents who are between 20-30years of age in the organization, many of them have less than ten years of working experience in the organization.

Finally, Table 4.1 shows that $66(35.3 \%)$ of the respondents were single, $102(54.5 \%)$ of our respondents were married, $13(7 \%)$ of our respondents were divorced and $6(3.2 \%)$ of our respondents are widowed. About 102 out of the total 187 respondents are married; these are very young employees of the organization who are just forming their own families.

\section{Hypotheses Testing}

To test the hypothesis, the Pearson's Product Moment Correlation and the regression model were adopted. The reason is that the Pearson's Correlation coefficient is used to test the relationship between variables and it also helps to show the strength and direction of the correlation while regression analysis helps to explain the proportion of the influence of independent variable on the dependent variable.

\section{Testing of Hypothesis 1}

$\mathrm{H}_{\mathrm{o}}=$ There is no significant influence of task crafting on employees' task performance in MTN Nigeria, PLC

$\mathrm{H}_{1}=$ There is a significant influence of task crafting on employees' task performance in MTN Nigeria, PLC. 
Table 4.2: Regression Model Summary for influence of Task Crafting on Employees' Task Performance

\begin{tabular}{lllclc}
\hline Model & $\mathrm{R}$ & R Square & Adjusted R Square & $\begin{array}{l}\text { Std. Error of the } \\
\text { Estimate }\end{array}$ \\
\hline 1 & $.297^{\mathrm{a}}$ & .088 & .083 & .64230 &
\end{tabular}

a. Predictors: (Constant), Task Crafting

The model summary Table 4.2 depicts the R-square value of the coefficient of determination, indicating a very low predictive power of $8.8 \%$. This implies that the task crafting has the ability to determine the employees' task performance at the rate of $8.8 \%$.

Table 4.3:ANOVA ${ }^{\mathrm{a}}$

\begin{tabular}{llcclcc}
\hline Model & & Sum of Squares & Df & Mean Square & F & Sig. \\
\hline & Regression & 7.362 & 1 & 7.362 & 17.844 & $.000^{\mathrm{b}}$ \\
1 & Residual & 76.322 & 185 & .413 & & \\
& Total & 83.684 & 186 & & & \\
\hline
\end{tabular}

a. Dependent Variable: Employees’ Task Performance

b. Predictors: (Constant), Task Crafting

Table 4.3 above shows the Analysis of Variance (ANOVA), it also shows statistical significance at $5 \%$ confidence interval, with the p-value less than 0.05 . The superscript $b$ reports significant predictors of the Task Crafting and the constant. Therefore, the null hypothesis of having the predictors not different from zero or being insignificant is rejected at 0.05 level of significance.

\section{Table 4.4: Coefficients $^{\mathrm{a}}$}

\begin{tabular}{|c|c|c|c|c|c|c|}
\hline \multirow{2}{*}{\multicolumn{2}{|c|}{ Model }} & \multicolumn{2}{|c|}{$\begin{array}{l}\text { Unstandardized } \\
\text { Coefficients }\end{array}$} & $\begin{array}{l}\text { Standardized } \\
\text { Coefficients }\end{array}$ & $\mathrm{T}$ & Sig. \\
\hline & & $\mathrm{B}$ & Std. Error & Beta & & \\
\hline \multirow{2}{*}{1} & (Constant) & 2.850 & .260 & & 10.954 & .000 \\
\hline & Task Crafting & .273 & .065 & .297 & 4.224 & .000 \\
\hline
\end{tabular}

a. Dependent Variable: Employees’ Task Performance 
Table 4.4 labelled Coefficients, checks the relevance of the independent variable (Task Crafting) on the employees' task performance in MTN Nigeria PLC. The B values represent the estimates of the model while the Beta value is used to check the predictive power of the model. From the above, the Beta value for the Task Crafting is relatively low (i.e. 29.7\%), indicating a low influence on the Employees' Task Performance, with p-value less than 0.05.

The model for the influence of Task Crafting on Employees' Task Performance can be seen as:

$\mathrm{Y}_{\text {employees' task performance }}=\beta 0+\beta 1 \mathrm{X}_{\text {Task crafting }}$

$\mathrm{Y}_{\text {employees' task performance }}=2.850+0.273 \mathrm{X}_{\text {Task crafting }}$

\section{Testing of Hypothesis 2}

$\mathrm{H}_{\mathrm{o}}=$ There is no significant relationship between relational crafting and organizational citizen behaviour in MTN Nigeria, PLC

$\mathrm{H}_{2}=$ There is a significant relationship between relational crafting and organizational citizen behavior in MTN Nigeria, PLC.

Table 4.5:Correlation Coefficient for Relational Crafting and Organizational Citizenship Behavior

$\begin{array}{ll}\text { Relational Crafting } & \begin{array}{l}\text { Organisational Citizen } \\ \text { Behaviour }\end{array}\end{array}$

\begin{tabular}{|c|c|c|c|}
\hline & Pearson Correlation & 1 & $.331^{* * *}$ \\
\hline \multirow[t]{3}{*}{ Relational Crafting } & Sig. (2-tailed) & & .000 \\
\hline & $\mathrm{N}$ & 187 & 187 \\
\hline & Pearson Correlation & $.331^{* *}$ & 1 \\
\hline \multirow[t]{2}{*}{$\begin{array}{l}\text { Organisational } \\
\text { Behaviour }\end{array}$} & Sig. (2-tailed) & .000 & \\
\hline & $\mathrm{N}$ & 187 & 187 \\
\hline
\end{tabular}

**. Correlation is significant at the 0.05 level (2-tailed).

Interpretation: Table 4.5 shows that relational crafting has a 0.331 correlation with organizational citizen behaviour. Based on the Pearson product moment correlation coefficient, there is a significant positive relationship between relational crafting and organizational citizen behaviour [Pearson's $\mathrm{r}_{\mathrm{p}}=0.331, \mathrm{n}=187, \mathrm{p}=0.000$ ]

R-value shows the direction and the strength of the correlation. The bigger the value, the more significant it is. The sign $(* *)$ indicates that there is a correlation between the variables. In this 
case, the Pearson product moment correlation shows a small but definite positive correlation between the variables under investigation. This means that the null hypothesis can be rejected since $\mathrm{p}=0.000^{*}$. The decision criteria here is to reject null hypothesis if $\mathrm{p} \leq 0.05$, this implies that the null hypothesis is rejected at a $95 \%$ confidence interval.

The correlation 0.331 between relational crafting and organizational citizen behaviour is significant at 0.05 level. As such, we reject the null hypothesis and accept the alternative hypothesis. This indicates that there is a significant positive relationship between relational crafting and organizational citizen behaviour in MTN Nigeria PLC.

\section{Discussion of Findings}

Summary of objective 1: The summary is to prove if the research question one was answered. Research question one was to find out if there was a significant influence of task crafting on employees' task performance. The result of objective one confirms that there is a low but positive significant influence of task crafting on employees' task performance at MTN Nigeria PLC.

This finding corroborates the work of Bohnlein and Baum (2020) on the effects of job crafting on individual in-role and extra-role performance. The findings in the present study revealed that some of the employees depend on the organization's job design as a source of task performance. Therefore the research findings gave answer to the research question and the alternative hypothesis one which stated that there is a significant influence of task crafting on employees' task performance was accepted.

The result of objective two also ascertains that there is a low significant positive relationship between relational crafting and organizational citizen behaviour in MTN Nigeria PLC. This finding is in tandem with the work of Peral and Geldenhuys (2020) on the relationship between personality traits and organisation citizen behavior through job crafting. The present findings show that employees are more productive and committed to the oragnisation when they are working with relevant individuals on the job that allows for collaboration. Therefore, the finding gave answer to the research question and the alternative hypothesis which stated that "there is a significant relationship between relational crafting and organizational citizen behaviour" was accepted.

\section{Conclusion}

In conclusion, it is hoped that this research study would provide guidance to MTN Head Office, Falomo, Lagos to improve its job crafting on employees' job performance. This is because majority of workers in MTN Head Office, Falomo, Lagos rely on the job crafting of the organization to improve their performance. From the study, it can be concluded that workers require a high degree of autonomy and independence on their jobs to perform more efficiently and effectively.

Similarly, the findings indicate that most workers in MTN also depend on the interpersonal relationship as a basis for further improving their productivity. Thus, workers in the organization often perform better when exposed to new individuals who can provide them with necessary skills on the job through collaboration or working as a team. In addition workers depend on their social interaction with their colleagues for effective job performance in the organization. 
This study should be seen as a key step in the formulation of a transformative guide for MTN and every other organizations as well as individuals who have access to this study to indicate problematic areas in working life at their respective organisations. It is hoped that the findings of this study will aid every organization but most especially MTN, Head Office, Falomo, Lagos to improve their employees' job performance by providing job crafting opportunities to them especially through the provision of suitable task crafting (i.e job design and structure) as well as relational crafting (i.e interpersonal relationship).

\section{Recommendations}

Based on the findings of this study, the following recommendations were made by the researchers:

1. The organization should provide a flexible job structure for its employees so as to enable them to better perform on the job. The work schedule should not be too rigid so as to enable the employees to perform their tasks more conveniently, thereby increasing effective performance.

2. Employees should be granted with a high level of autonomy, authority and independence in performing their tasks. This in turn, will boost employees' morale thereby increasing their commitment and sense of belongingness.

3. The organization should also promote team building among the employees so that ideas and skills can be shared within the organisation. Through this, the workers are able to acquire further information and knowledge that are pivotal to their task performance from their co-workers.

Finally, this study recognizes the fact that there are limitations as to the number of respondents and scope of study. Therefore, it is suggested that further studies should be conducted with a larger sample and wider scope. Furthermore, since the research study was focused on a private sector, it is also recommended that a replicated studies can also be carried out in the government/public sector as well as conducting a comparative analysis of the same topic from both sectors.

\section{References}

Austin, J. T. \& Villanova, P. (1992). The criterion problem: 1917-1992. Journal of Applied Psychology, 836-874

Bakker, A. B. (2011). An evidence-based model of work engagement. Current Directions in Psychological Science, 20, 265-269.

Bakker, A. B., \& Bal, P.M. (2010). Weekly work engagement and performance: A study among starting teachers. Journal of Occupational and Organizational Psychology, 83, 189-206.

Bakker, A. B., \& Demerouti, E. (2007). The job demands-resources model: State of the art. Journal of Managerial Psychology, 22, 309-328. 
Bakker, A. B., \& Demerouti, E. (2014). Job demands-resources theory. In Chen, P.Y. \& Cooper, C.L. (Eds.), Work and Wellbeing: A complete reference guide (Volume III; 3764). Chichester, UK: Wiley-Blackwell.

Bakker, A. B., \& Demerouti, E. (2014). Job demands-resources theory. Well-being, 3, 1-28.

Bakker, A. B., Tims, M., \& Derks, D. (2012). Proactive personality and job performance: The role of job crafting and work engagement. Human Relations, 65 (10), 1359-1378.

Berg, J. M., Dutton, J. E., \&Wrzesniewski A. (2013). Job crafting and meaningful work. San Francisco. CA: Berrett-Koehler

Bindl, U. K., \& Parker, S. K. (2011). Proactive work behavior: Forward thinking and changeoriented actions in organizations. In Zedeck, S. (Eds.) APA handbook of Industrial and Organizational Psychology, Volume 2 Selecting and developing members of the organization. Washington DC: American Psychological Association, 567-598

Bohnlein, P. \& Baum, M. (2020). Does job crafting always lead to employee well-being and performance? Meta-analytical evidence on the oderating role of societal culture. The International Journal of Human Resource Management, 1-39

Borman, W. C., \&Motowidlo, S. J. (1993). Expanding the criterion domain to include elements of contextual performance. Personnel Selection in Organizations; San Francisco: JosseyBass, 71.

Borman, W. C., \&Motowidlo, S. J. (1997). Task performance and contextual performance: The meaning for personnel selection research. Human performance, 10, 99-109

Buchner, T. W. (2007). Performance management theory: A look from the performer's perspective with implications for HRD. Human Resource Development International, $10(1), 59-73$.

Cable, D. M., \& De Rue (2002). The convergent and discriminant validity of subjective fit perceptions. Journal of Applied Psychology, 87(5), 875-884.

Casio, W.F. \&Aguinis, H. (2014). Applied psychology in human resource management. Essex: Pearson Education Limited

Champion, M. A. (1988). Interdisciplinary approaches to job design: A constructive replication with extensions. Journal of Applied Psychology, 73(3), 467-481.

Chen, G., Gully, S. M. \& Eden, D. (2001). Validation of a new general self-efficacy scale. Organizational Research Methods 4(1), 62-83.

Christian, M. S., Garza, A. S., \& Slaughter, J. E. (2011). Work engagement: A quantitative review and test of its relations with task and contextual performance. Personnel Psychology, 64, 89-136. 
Crawford, E. R., LePine, J. A., \& Rich, B. L. (2010). Linking job demands and resources to employee engagement and burnout: A theoretical extension and meta-analytic test. Journal of Applied Psychology, 95, 834-848.

Crant, J. M. (2000). Proactive behavior in organizations. Journal of Management, 26(3), 435462.

Dalal, R. S. (2005). A meta-analysis of the relationship between organizational citizenship behavior and counter-productive work behavior. Journal of Applied Psychology, 90, 1241-1255.

Demerouti, E. (2014).Design your own job through job crafting. European Psychologist, 19 (4), 237-247.

Demerouti, E., Bakker, A. B., Nachreiner, F., \&Schaufeli, W. B. (2001). The job demandsresources model of burnout. Journal of Applied Psychology, 86, 499-512.

Dik, B.J., Bryne, Z. S. \& Steger, M. F. (2000). Purpose and meaning in the workplace (pp. 81-104). Washington, DC: American Psychological Association.

Frese, M., Fay, D., Hilburger, T., Leng, K. \& Tag, A. (1997). The concept of personal initiative: Operationalization, reliability and validity in two German samples. Journal of Occupational and Organizational Psychology, 70, 139-161.

Frese, M., Garst, H., \& Fay, D. (2007). Making things happen: Reciprocal relationships between work characteristics and personal initiative in a four-wave longitudinal structural equation model. Journal of Applied Psychology, 92, 1081-1102.

Fritz, C., \&Sonnentag, S. (2009). Antecedents of day-level proactive behavior: A look at job stressor and positive affect during the work day. Journal of Management, 35, 94-111.

Genty, K.I., Fapohunda, T.M., Jayeoba, F.T., \& Azeez, R.O. (2017). Workplace spirituality and organizational citizenship behavior among academics: the mediating role of normative organizational commitment. Journal of Human Resource Management, XX (2), 48-62.

Ghitulescu, B. E. (2006). Shaping task and relationships at work: Examining the antecedents and consequences of employee job crafting. Unpublished Doctoral dissertation, University of Pittsburgh

Grant, A. M., \& Ashford, S. J. (2008). The dynamics of proactivity at work. Research in Organizational Behavior28(1), 3-34.

Grant, A. M., \& Parker, S. K. (2009). Redesigning work design theories: the rise of relational and proactive perspectives. The Academy of Management Annals, 3, 273-331.

Greenberger, D. B. (1981). Personal control at work: Its conceptualization and measurement. Technical report, University Wisconsin-Madison

Gruys, M. L. (1999). The dimensionality of deviant employee performance in the workplace. Unpublished Doctoral dissertation, University of Minnesota, Minneapolis, M. N., USA 
Hackman, J. R. \& Oldham, G. R. (1976). Motivation through the design of work: Test of a theory. Organizational Behavior and Human Performance, 16 (2),250-279.

Hobfoll, S. E. (2001). The influence of culture, community and the nested-self in the stress process: Advancing conservation of resources theory. Applied Psychology: An International Review, 50, 337-370.

Karasek, R. A. \& Theorell, T. (1990). Healthy work: Stress productivity and the reconstruction of working life. New York: Basic books

Leana, C., Appelbaum, E. \&Shevchuk, I. (2009). Work process and quality of care in early childhood education: the role of job crafting. Academy of Management Journal 52(6), 1169-1192.

Leary, M. R., Kelly, K. M., Cottrell, C. A. \&Schreindorfar, L. S. (2006). Construct validity of the need to belong scale: Mapping the homological network. Journal of Personality Assessment, 95(6), 610-624.

LePine, J. A, Podsakoff, N. P, \&LePine, M. A. (2005). A meta-analytic test of the challenge stressor-hindrance stressor framework: An explanation for inconsistent relationship among stressors and performance. Academy of Management Journal, 48, 764-775.

Lee, F. (1997). When the going gets tough, do the tough ask for help? Help seeking and power motivations in the organization. Organization behavior and human decision processes, 73, 336-363

Li, H., Jin, H., \& Chen, T. (2018). Linking proactive personality to creative performance: the role of job crafting and high-involvement work system. The Journal of Creative

Behaviour, 0(0), 1-15.

Mackenzie, S. B., Podsakoff, P. M. \& Fetter, R. (1991). Organizational citizenship behavior and objective productivity is determinant of managerial evaluations of salespersons. Organizational behavior and human decision processes, 50, 123-150

Morrison, E. W. \& Phelps, C. C. (1999). Taking charge at work: extra role efforts to initiate workplace change. Academy of Management Journal, 42(4), 403-419.

Ogbuanya, T.C., \&Chukwuedo, S.O. (2017). Job crafting-satisfaction relationship in electrical/electronic technology programme. Do work engagement and commitment matter? Journal of Work and Organzational Psychology, (In press)

Oldham, G. R. \& Hackman, J. R. (2010). Now what it was and not what it will be: the future of job design research. Journal of Organizational Behavior 31(2-3), 463-479.

Parker, S. K., Bindl, U. K. \& Strauss, K. (2010). Making things happen: A model of proactive motivation. Journal of Management 36, 827-856.

Peng, C.Y. (2018). A literature review of job crafting and its related researches. Journal of Human Resource and Sustainability Studies, 6, 1-7 
Peral, S.L., \& Geldenhuys, M. (2020). The indirect relationship between personality and performance through job crafting behavior. SA Journal of Industrial Psychology, 46, 1-12

Poell, R. F., \& Van Der Krogt, F. J. (under review). Why is organizing human resource development so problematic? Perspectives from the learning-network theory. The International Journal of Human Resource Management, 54(3), 32-36.

Rotundo, M. \& Sackett, P. R. (2002). The relative importance of task, citizenship and counterproductive performance to global ratings of job performance: A policy-capturing approach. Journal of Applied Psychology, 87, 66-80.

Salanova, M., \& Schaufeli, W. B. (2008). A cross-national study of work engagement as a mediator between job resources and proactive behavior. The International Journal of Human Resource Management, 19, 116-131.

Staufenbiel, T. \& Hartz, C. (2000). Organizational citizenship behavior: Development and validation of measurement instrument. Diagnostica, 46(2), 73-83.

Tafordi, R. W. \& Swann, W. B. (2001). Two-dimensional self-esteem: theory and measurement. Personality and Individual Differences, 31(5), 653-673.

Tims, M., Bakker, A. B., \& Derks, D. (2012). Development and validation of the job crafting scale. Journal of Vocational Behavior, 80 (1), 173-186.

Tims, M., Bakker, A. B., \& Derks, D. (2015). Job crafting and job performance: a longitudinal study. European Journal of Work and Organizatonal Psychology, 24(6), 914-928.

Van den Broeck, A., Van Steenkist, M., De Witte, H. \& Lens, W. (2008). Explaining the relationships between job characteristics, burnout and engagement: The role of basic psychological needs satisfaction. Work and Stress 22(3), 277-294.

Van Wingerden, J., Derks, D., \& Bakker, A. B. (2015). The impact of personal resources and job crafting interventions on work engagement and performance. Human Resource Management

Vogt, H., Hakanen, J.J., Brauchi, R., Jenny, G.J., \& Bauer, G.F.(2015). The consequences of job crafting: a three-wave study. European Journal of Work and Organizational Psychology, 25(3), 353-362.

Wrzesniewski, A. (2016). Finding positive meaning in work. In Cameron, K. S., Dutton, J. E. \& Quinn, R. E. (Eds.), Positive organizational scholarship: Foundations of a new discipline San Francisco. CA: Berrett-Koehler.

Wrzesniewski, A., \& Dutton, J. E. (2001).Crafting a job: revisioning employees as active crafters of their work. Academy of Management Review, 26, 179-201.

Xanthopoulou, D., Bakker, A.B., Demerouti, E. \& Schaufeli, W. B. (2009). Reciprocal relationship between job resources, personal resources and work engagement. Journal of Vocational Behavior, 74(3), 235-244. 